\title{
Intraoperative topical administration of mitomycin C, in different concentrations, on the cicatrization of mioplasties of the dorsal rectus of rabbits
}

\author{
Administração tópica per-operatória da mitomicina C, em diferentes concentrações, sobre a cicatrização de \\ mioplastias do reto dorsal de coelhos
}

\author{
Fabrício Villela Mamede ${ }^{\mathrm{I}}$ Bianca da Costa Martins ${ }^{\mathrm{I}}$ Ana Letícia Groszewicz Souza \\ Adriana Torrecilhas Jorge Brunelli ${ }^{I I}$ Karina Pontin ${ }^{\text {III }}$ Edson Garcia Soares ${ }^{\text {IV }}$ \\ Sérgio de Albuquerque ${ }^{\mathrm{V}}$ José Luiz Laus ${ }^{\mathrm{I}^{*}}$
}

\begin{abstract}
Myoplasties of the extraocular muscle may cause adhesions between the operated muscle and the adjacent tissues, commonly generating cicatricial strabismus. With the purpose of reducing to a minimum the occurrence of adhesion, the effects of mitomycin $C$, an antifibrotic agent, were studied in concentrations of $0.008 \%, 0.02 \%$, and $0.04 \%$ applied during intraoperative of myoplasties of the superior rectus muscle of rabbits. Fifty six animals were divided in five groups. During the postoperative, the operated areas were washed with physiological solution. Eye drop instillation to prevent inflammation and bacterial infection were used. The method to analyze the results consisted of clinical and histological evaluation and statistical analyzes. We also evaluated at the same time the amount of basic fibroblast growth factor (FGF2) by immunohistochemical study. Clinically, more adhesions were found in the eyes of the control group than in the groups of treated eyes. However there was no significant statistics difference between the two groups $(P>0.05)$. Histologically, mitomycin $C$ caused a delayed cicatrization in the mioplastic areas, specially in the group who received the $0.02 \%$ concentration. The immunohistochemical showed FGF-2 marking in fibroblasts and macrophages, but between the groups there wasn't no difference. Based on those results, mitomycin $C$ in the utilized concentrations was capable of delaying the cicatrization and consequently avoid the secondary strabismus without undesirable side effects.
\end{abstract}

Key words: adhesions, mitomycin C, myoplasty, eye.

RESUMO

Mioplastias da musculatura extra-ocular podem ensejar aderências entre o músculo operado e os tecidos adjacentes, produzindo, não raro, estrabismos cicatriciais. Com intuito de se minimizar a ocorrência de aderências, investigaram-se os efeitos da mitomicina $C$, como agente antifibrótico, em concentrações ascendentes de 0,008, 0,02 e $0,04 \%$, aplicada no per-operatório de mioplastias do reto superior do bulbo do olho de coelhos. Operaram-se 56 animais, que compuseram cinco grupos. No pós-operatório, instituíramse limpeza com solução fisiológica das áreas operadas e profilaxia antimicrobiana e antiinflamatória, na forma de colírio. Avaliações clínica, histológica e imunoistoquímica, em que se estudou o fator de crescimento fibroblástico-básico (FGF-2), e estatística compuseram os métodos de análise dos resultados. Encontraram-se, clinicamente, mais aderências nos olhos-controle, comparativamente aos tratados, embora sem diferença estatística $(P>0,05)$. À histologia, verificou-se que a mitomicina $C$ ensejou retardo da cicatrização junto às áreas das mioplastias, notadamente no grupo que a recebeu, à concentração de 0,02\%. A imunoistoquímica revelou marcação do FGF-2 em fibroblastos e macrófagos indistintamente entre os grupos. Com base nos resultados, permite-se admitir que a mitomicina $C$, nas concentrações em que foi empregada, retardou a cicatrização e, por conseguinte, o estrabismo secundário, sem ensejar efeitos colaterais.

Palavras-chave: aderência, mitomicina $C$, mioplastia, olho.

\section{INTRODUCTION}

Myoplasties of extra ocular muscle may cause adhesions between the operated muscle and the adjacent tissues, allowing the occurrence of oculomotor dysfunctions and cicatricial strabismus (CRUZ, 1996).

\footnotetext{
IFaculdade de Ciências Agrárias e Veterinárias (FCAV), Universidade Estadual Paulista (UNESP), Campus de Jaboticabal, SP, Brasil. E-mail: jllaus@fcav.unesp.br.*Autor para correspondência.

IIAutônoma.

IIIInstituto de Biologia, Universidade de Campinas (UNICAMP), Campinas, SP, Brasil.

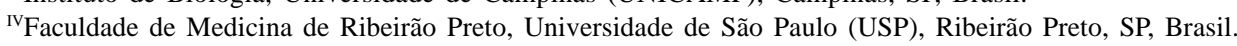

vFaculdade de Ciências Farmacêuticas de Ribeirão Preto, USP, Ribeirão Preto, SP, Brasil.
} 
To prevent them physical barriers have been tested such as gelatinous sponge of animal skins, synthetic polypeptides, polyglactin 910, viscoelastic substances, capsules of Tenon and silicone (SILVA, 1983; ELSAS et al., 1992; HWANG \& CHANG, 1996). Furthermore anticicatricial agents were also used such as daunorubicin, bleomycin, mitramycin, 5-fluoracil, cyanoacrylate and mitomycin C (LEE et al., 1990; CRUZ, 1996; MAMEDE et al., 2004).

Antifibrotic effects of mitomycin $C$ have been reported in in vitro and in vivo studies (KUNITOMO \& MORI, 1969; YAMAMOTO et al., 1990). There have been several communications regarding the use of antifibrotics effects in the correction of strabismus in concentration varying from 0.02\% to 0.05\% (BROOKS et al., 1996; CRUZ, 1996; OH et al., 1999; MINGUINI et al., 2000; MAHINDRAKAR et al., 2001; MAMEDE et al., 2004). Those studies evaluated the effects of mitomycin $\mathrm{C}$ after its utilization on myoplasties, by contact between the substances and the tissues in time periods varying from 1 to 5 minutes (BROOKS et al., 1996; CRUZ, 1996; OH et al., 1999; MINGUINI et al., 2000; MAMEDE et al., 2004).

Despite the good results confirmed by many researchers, there have been some controversies about the efficacy of mitomycin $\mathrm{C}$ as an antifibrotic agent (BROOKS et al., 1996; MINGUINI et al., 2000). Side effects have been reported such as discomfort, persistent photophobia, conjunctival hyperemia and chemosis. Conjunctival granulomas, punctiform keratitis, melting and perforation of the cornea, areas of scleral calcifications, secondary glaucoma and cataract have also been reported. (RUBINFELD et al., 1992; ANDUZE \& BURNETT, 1996; DOUGHERTY et al., 1996; MAMEDE et al., 2004).

The present study aimed at investigating the antifibrotic action of mitomycin C, applied during the myoplastic of the dorsal rectus, in different concentrations, based on the clinical, histological and immunohistochemical studies.

\section{MATERIAL AND METHODS}

Prior to its performance the research project was evaluated and approved by the 'Chamber of Ethics in Animal Research' of the College of Agricultural and Veterinarian Sciences, São Paulo University - UNESP Jaboticabal, São Paulo, Brazil. The rules of Association for Research in Vision and Ophthalmology -ARVO (National Institutes of Health Publications №. 85-23: Revised 1985) and the Nüremberg Code (GOLDIM, 1995) were also complied with.

Fifty-six rabbits (Oryctolagus cuniculus, LILLJEBORG, 1874) of the New Zealand race, adults, males and females, weighing above $2 \mathrm{~kg}$ were utilized. They were divided in five categories: Negative Control Group (NCG), Positive Control Group (PCG) and groups subjected to treatment with mitomycin $\mathrm{C}$ in the concentrations $0.008 \%$ (GT-1) $0.02 \%$ (GT-2) and $0.04 \%$ (GT-3).

To minimize the effects of individual variations and to increase the amount of samples, both eyes of each animal were utilized excepting the animals of the control group, NCG, which had only one of the eyes operated. The dorsal rectus muscle was recessed 5 to $8 \mathrm{~mm}$. In the NCG, $0.9 \%$ physiological solution was instilled in the myoscleral suture for 5 minutes. And in the PCG, after the recession, a $0.9 \%$ physiological solution was instilled in the myoscleral suture for five minutes, and in the contra-lateral eye the effects of mitomycin $\mathrm{C}$ were evaluated. This group was study considering the possibility of the mitomycin $\mathrm{C}$ affecting the untreated eye by absorption and systemic dissemination.

In the groups GT-1, GT-2 and GT-3 after the recession of the dorsal rectus muscle, mitomycin $\mathrm{C}$ in the concentration of $0.008 \%, 0.02 \%$ and $0.04 \%$ was instilled on the myoscleral suture for five minutes.

To perform the surgical techniques the rabbits were anesthetized with xilazina $\left(5 \mathrm{mg} \mathrm{kg}^{-1}\right.$, IV) (Virbaxyl 2\% - Cloridrato de xilazina - Virbac-São Paulo, SP, Brasil) and ketamina (25mg kg-1 IV) (Vetaset Cloridrato de Quetamina - Fort Dodge - Campinas, SP, Brasil) and maintained in the anesthetic plan with halothane (Fluothane - Halotano - AstraZeneca Cotia, SP, Brasil) in a semi open circuit (KOHN et al., 1997). The employed surgical technique for the muscle recession and myoplasties was the divulsion of the bulbar conjunctiva from the corneosclera limbus between 11 and 14 hours of a clock, identification and isolation of the dorsal rectus muscle, resection close to its scleral insertion and myoscleral suture with Vicryl 6-0 (Vicryl 6-0 (J544G)- Poliglactina 910 - Ethicon São José dos Campos, SP, Brasil) (Figure 1) (PARKS, 1983). Afterwards physiological solution or mitomycin $\mathrm{C}$ in the different concentrations were applied on the myoplastic areas. After the surgical procedures the area was washed with physiological solution and the suture of the capsule of Tenon and bulbar conjunctiva was performed using Vicryl 6-0.

During the postoperative period the ocular surface was submitted to daily rinsing and prophylactic instillation of eye drops composed of neomycin, polymyxin B and dexamethasone (Maxitrol - Sulfato de Neomicina, Sulfato de Polimixina B e Dexametasona - Alcon do Brasil - São Paulo, SP, Brasil) every six

Ciência Rural, v.38, n.1, jan-fev, 2008. 


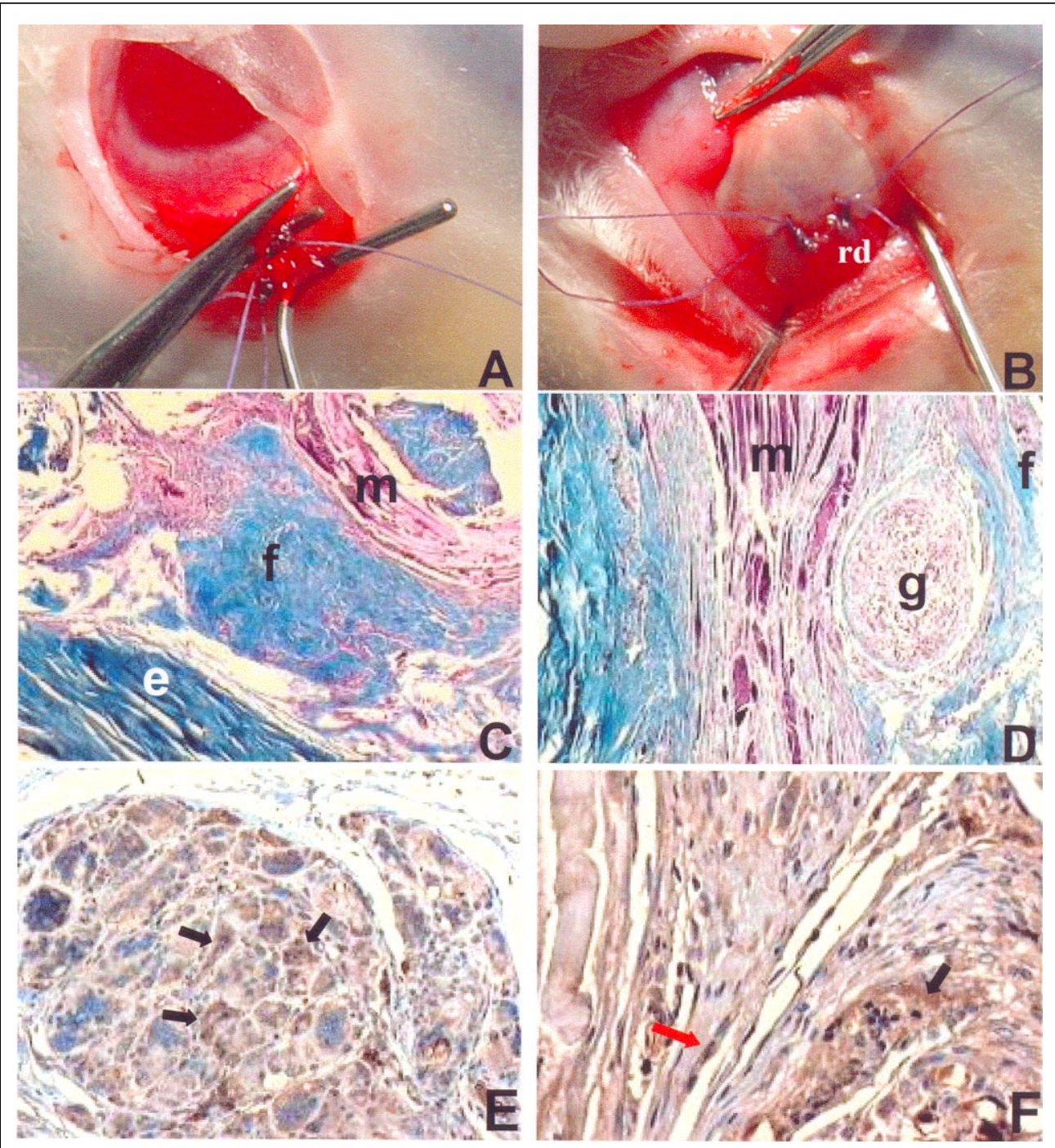

Figure 1 - Photographic and photomicrographs images of mioplasties of dorsal rectus of laboratory albino adult rabbits in different groups and periods. A - Transfixion of the muscle prior to recession. B - Myoscleral suture of the rectus dorsal muscle (rd). C - 15 days- PCG: intense fibrosis (f) between the muscle (m) and the sclera (e) (Tric, 60x). D - 30 days - PCG: moderate fibrosis around the granuloma (g) and between the muscular fibers (m) (Tric, 60x). E - 15 days - NCG: Moderate expression of FGF-2 in macrophages (black arrows) (Immunohistochemical, 150x). F - 30 days - GT-1: moderate marking of FGF-2 in macrophages (black arrow) and in fibroblasts (red arrow) (Immunohistochemical, 300x).

hours for seven consecutive days. For pain control buprenorphine (Temgesic $0.3 \mathrm{mg} \mathrm{ml}^{-1}-$ Cloridrato de Buprenorfina - Schering-Plough - Rio de Janeiro, RJ, Brasil) was administered subcutaneously in the dosage of $0.01 \mathrm{mg} \mathrm{kg}^{-1}$ every 12 hours for five consecutive days. The parameters concerning chemosis, blepharospasm, conjunctival hyperemia, hemorrhage, secretion and strabismus were evaluated for up to 120 days. Qualitative and quantitative criteria were followed: absent (nihil), discrete $(+)$, moderate $(++)$ and intense (+++).
Macroscopical, histological and immunohistochemical evaluation of the myoplastic areas were conducted for the postoperative periods of 15, 30, 60 and 120 days. For this purpose the animals were again subjected to anesthesia following the adopted protocol for the surgical procedures.

For adhesions evaluations as a quantity criterion, nihil represents absence of adhesions, $(+)$ few adhesions, $(++)$ moderate adhesions, $(+++)$ many adhesions. To evaluate its intensity the adhesions were qualified from 0 to 4 , where 0 - absence of adhesions; 1 - 
limited adhesions easily separated by dissection. 2 mild to moderate adhesions; 3 - moderate to dense adhesions with difficult dissection and 4 - strong nondissectible adhesions.

For histopathological purposes, tissues containing sclera and muscular portions were extracted from the adjacent surgical areas. They were fixed for 24 hours in $10 \%$ buffered formalin and sectioned in paraffin. Sections of $5 \mu \mathrm{m}$ were prepared and the laminas were stained with hematoxylineosin and Masson's Trichrome. Thereafter, for scientific documentation purposes, a photomicroscope was used to evaluate the cells and events related to fibrosis. In addition, immunohistochemical was used to demonstrate FGF-2.

The quantified events were analysis statistically using Kruskal-Wallis (one-way analysis of variance for nonparametric data) with the level of significance set at $5 \%(\mathrm{P}=0.05)$.

\section{RESULTS}

The clinical evaluation of the operated eyes showed chemosis only in the first days of the postoperative follow up. Moderate levels of blepharospasm were assessed on the first day of evaluation only in the NCG animals. In the other groups blepharospasm was absent or present in minimal levels. Intense conjunctival hyperemia was observed up to the fifth day of evaluation in the majority of the animals of every group, tending to diminish in the subsequent periods. Ocular hemorrhage was not observed during the evaluation process. Secretion, when present, was of the mucous type and appeared moderately in the NCG animals. In the other groups the secretion, when present, was even discrete. Statistical differences were not observed (Figure 2).

Discrete to moderate hypotropia was observed. At every moment of the evaluation the eyes treated with mitomycin $\mathrm{C}$, regardless its concentration, showed adhesions in lesser significant quantities and levels when compared to the control group of myoplasties. However statistical difference was found only between PCG and GT-3, at the $15^{\text {th }}$ postoperative day $(\mathrm{P}<0.01)$ (Figure 2).

In the early stages of the follow up, the histological evaluation showed intense granulomatous and lymphocytic inflammatory reaction at the mioplastic areas. The granulomatous reaction occurred similarly between the groups on the $15^{\text {th }}, 30^{\text {th }}$ and $60^{\text {th }}$ Postoperative. On the $120^{\text {th }}$ day, half the animals of the GT-2 group showed a delayed involution. Regarding the fibrosis, on the $15^{\text {th }}$ day a smaller incidence was observed in the control groups when compared to treated groups. However after 15 days it was observed a tendency to an increase of fibrosis in the control groups and a decrease in the groups treated with mitomycin C. At the end of the evaluation (120 days) the groups showed moderate and with no significant differences (Figure 1).

Immunohistochemical evaluation showed expression of the FGF-2 in fibroblasts and macrophages in different grades and variables, according to the periods of the evaluation. At 15 day it was observed moderate to intense expressions in the animals of NCG groups. In the other groups they varied from discrete to moderate. At 30 day it was observed a great increase in the FGF-2 expressions in all groups. In the NCG group it evolved to an intense grade while in the other groups it was maintained in moderate. After 60 days it was observed a great decrease in the FGF-2 marking in every group, evolving to a discrete on day $120^{\text {th }}$ (Figure 1 ).

\section{DISCUSSION}

The clinical evaluation indicates that most animals showed, at some moment of the postoperative, signs of chemosis, blefarospasm, conjunctival hyperemia and mucous ocular secretion. Chemosis was present in the acute phases of the postoperative and in a discrete form in every animal. Due to its pattern and rapid development we believe it was caused by surgical trauma. The conjunctival hyperemia, present especially in the early days of evaluation, is also due to the surgical procedures. The hyperemia was more intense in the area around the suture as reported by DADEYA \& KAMLESH (2001). In general the qualified and quantified clinical signs showed no differences between the groups, allowing us to assume that mitomycin $\mathrm{C}$ as applied in the intraoperative did not induce exudation in the eyes surface, in opposition to the findings of MAMEDE et al. (2004) when it was utilized in the postoperative for 14 days.

Adhesions were present in all of myoplasties. When we compared the NCG and PCG groups no differences were seen. Those findings lead us to assume that mitomycin C, according to the utilized protocol, was not absorbed by systemic via in enough quantity to produce any effect in the contra-lateral eyes. The findings confirm those of MATTAR et al. (1995), who inform that mitomycin C acts only in the applied area.

When comparing the NCG and PCG groups with the groups treated with mitomycin C (GT-1, GT-2, GT-3) it was found in the controls a greater quantity and grades of adhesion in all evaluated periods. Those 

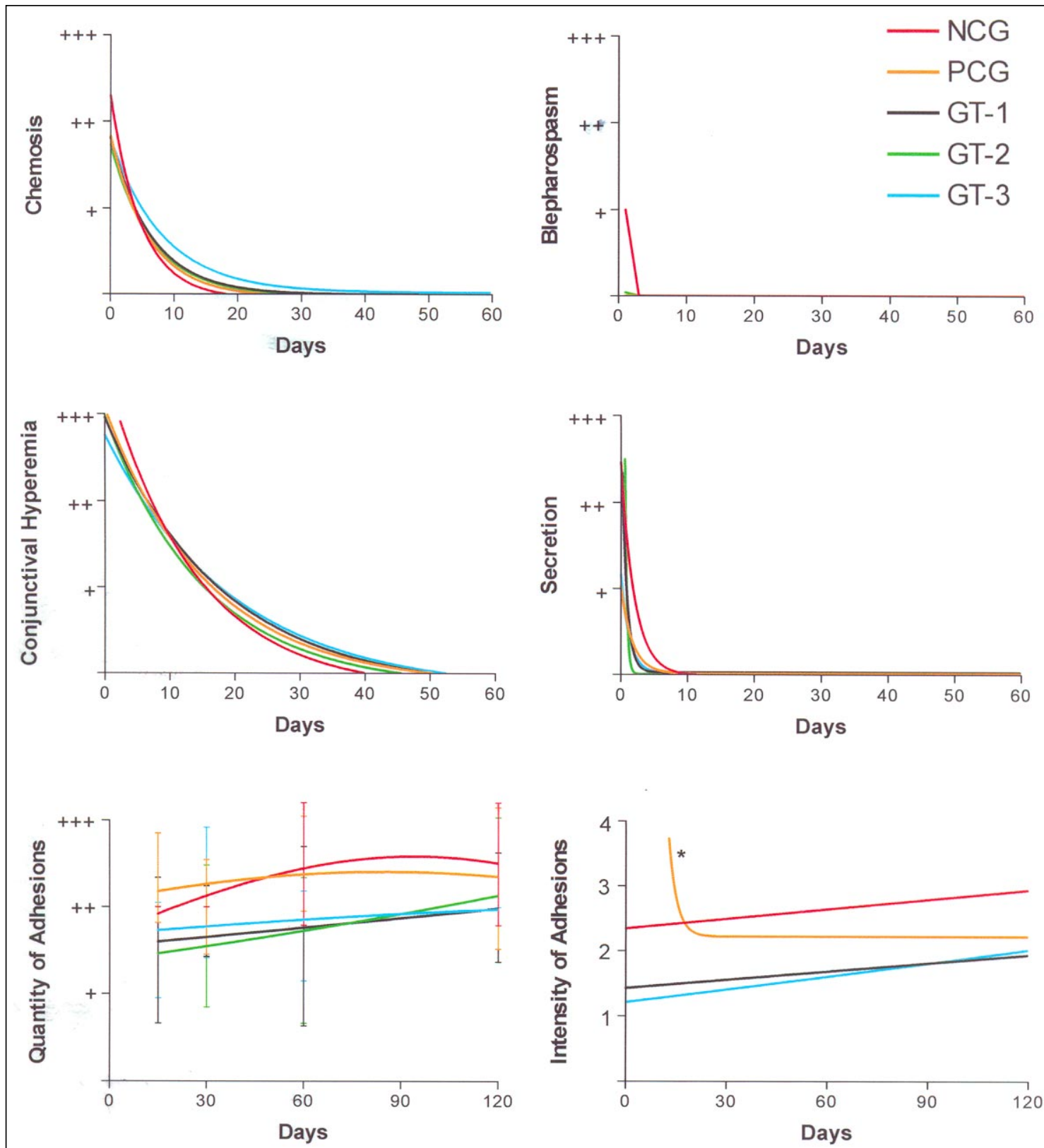

Figure 2 - Graphics representations of the quantities of chemosis, blefarospasm, conjunctival hyperemia, secretion, adhesions and intensity of adhesions of the groups Negative Control Group (NCG), Positive Control Group (PCG), GT-1, GT-2 and GT-3, truth the evaluations.

findings corroborate CRUZ \& MATKOVICH (1995), CRUZ (1996) OH et al. (1999) and MAHINDRAKAR et al. (2001). However, despite the confirmation of these facts, statistically there was no difference, except when comparing the PCG and GT-3 on $15^{\text {th }}$ postoperative. Adhesions were present in a similar form in the groups treated with mitomycin $\mathrm{C}$ in different concentrations. Therefore it is assumed that the use of smaller concentration has the same antifibrotic effect.

Inflammatory reaction of the granulamatous and lymphocytic type, as seen in the early stages of the postoperative, was similar to the findings of INGRAM (1965), who studied in rabbits the effects caused by recess of the extrinsic muscle of the eyes without the interference of any drugs. Therefore it is fair to assume that the surgical procedure and the suture material have caused this inflammatory reaction.

The granuloma that was formed in the myoplastic areas occurred in the same way between the groups, in the evaluation periods of 15,30 and 60 days. On the $120^{\text {th }}$ day there was a delayed involution 
of the granuloma in $50 \%$ of the animals treated with mitomycin C at $0.02 \%$ (GT-2). Fibrosis occurred more intensively in the treated groups until 60 days. Afterwards it was equivalent to the mitomycin $\mathrm{C}$ control groups. Therefore we assume that mitomycin $\mathrm{C}$ may have slowed the occurrence of fibrosis on the applied area, which corroborate the results found by RIBEIRO et al. (2003), who study the effects of mitomycin C in rat's derma.

Regarding the immunohistochemical, the FGF-2 expressed for fibroblasts as well as for macrophages confirms the findings of FUNATO et al. (1999) and WANG et al. (2001). In the present research the intensity of the expression of FGF-2 occurred in a very similar way between the studied groups. Those results oppose the findings of $\mathrm{OH}$ et al. (1999), which reported a smaller expression in animals that received mitomycin C. Since FGF-2 is produced by macrophages, fibroblasts, mast cells, lymphocytes $\mathrm{T}$ and by endothelial cells (KUMAR et al., 2005) and if mitomycin C has effect only over fibroblastic proliferation (YAMAMOTO et al., 1990), we admit that it has little interference on the production of FGF-2.

\section{CONCLUSIONS}

Based on our investigation, it is possible to admit that mitomycin $\mathrm{C}$ allows clinical occurrence of smaller adhesions in the myoplastic areas, although the result was not statistically significant. Under light microscope study mitomycin $C$ delayed the occurrence of fibrosis formation in the myoplastic areas, especially in the $0.02 \%$ concentrations. According to immunohistochemical analyses, the FGF-2 suffered no interference from mitomycin $\mathrm{C}$ effect in any moment of the evaluation. The clinical evaluation showed no side effects by using the mitomycin $\mathrm{C}$.

\section{ACKNOWLEDGEMENT}

The authors are grateful to FAPESP ( Proc. $n^{\circ}$ 03/ 09527-0), CAPES (Capes-Proap - Demanda social) and FUNDUNESP (Proc. nº 00743/03-DFP) for the financial support.

\section{REFERENCES}

ANDUZE, A.L.; BURNETT, I.M. Indications for and complications of mitomycin $\mathrm{C}$ in pterygium surgery. Ophthalmic Surgery Lasers, Thorofare, v.27, p.667-673, 1996.

BROOKS, S.E. et al. Fat adherence syndrome treated with intraoperative mitomycin C: a rabbit model. Journal Pediatric Ophthalmology Strabismus, Thorofare, v.33, n.1, p.21-27, 1996.
CRUZ, O.A.; MATKOVICH, L. Effects of intraoperative topical mitomycin-C on strabismus surgery in the rabbit: a preliminary study. Ophthalmic Surgery, Thorofare, v.26, n.3, p.237-240, 1995.

CRUZ, O.A. Evaluation of mitomycin to limit postoperative adhesions in strabismus surgery. Journal Pediatric Ophthalmology Strabismus, Thorofare, v.33, p.89-92, 1996.

DADEYA, S.; KAMLESH, M.S. Strabismus surgery: fibrin glue versus vicryl for conjunctival closure. Acta Ophthalmology Scandinavia, Copenhagen, v.79, p.515-517, 2001.

DOUGHERTY, P.I. et al. Corneal scleral melt after pterygium surgery using a single intraoperative application of mitomycin C. Cornea, London, v.15, p.537-540, 1996.

ELSAS, F.J. et al. Synthetic polypeptide sleeve for strabismus surgery. Journal Pediatric Ophthalmology Strabismus, Thorofare, v.29, p.284-286, 1992.

FUNATO, N. et al. Evidence for apoptosis induction in myofibroblasts during palatal mucoperiosteal repair. Journal of Dental Research, Washington, v.78, n.9, p.1511-1517, 1999.

GOLDIM, J.R. Pesquisa em saúde e direitos dos animais. Porto Alegre: HCPA, 1995. 28p.

HWANG, J.; CHANG, B.L. Use of physical barriers for delay adjustable strabismus surgery: the effect of Interceed and polyglactin 910 mesh. British Journal Ophthalmology, London, v.80, p.759-762, 1996.

INGRAM, R.M. Tissue repair after the operations of recession and resection. Bristish Journal Ophthalmology, London, v.49, p.18-28, 1965.

KOHN, D.F. et al. Anesthesia and analgesia in laboratory animals. San Diego: Academic, 1997. 426p.

KUMAR, V. et al. Robbins and Cotran pathologic bases of disease. 7.ed. Philadelphia: Elsevier Saunders, 2005.

KUNITOMO, N.; MORI, S. Study on the pterigium: part IV, a treatment of the pterigium by mitomicin $\mathrm{C}$ instilation. Acta Societatis Ophthalmologicae Japonicae, Tokyo, v.67, p.601-607, 1969.

LEE, D.A. et al. Effects of mithramycin, mitomycin, daunorubicin and bleomycin on human subconjunctival fibroblast attachment and proliferation. Investigative Ophthalmology and Visual Science, Saint Louis, v.31, p.2136-2144, 1990.

MAHINDRAKAR, A. et al. Effectiveness of mitomycin C in reducing reformation of adhesions following surgery for restrictive strabismus. Journal Pediatric Ophthalmology Strabismus, Thorofare, v.38, p.131-135, 2001.

MAMEDE, F.V. et al. Use of topical mitomycin C in myoplasty of the medial rectus muscle of rabbits. Veterinary Ophthalmology, Gainesville, v.7, n.5, p.335-342, 2004.

MATTAR, D.B. et al. Estudo da influência da aplicação subconjuntival da mitomicina $C$ na reparação de defeito epitelial corneano, em coelhas. Arquivos Brasileiro de Oftalmologia, São Paulo, v.58, n.1, p.65-67, 1995. 
MINGUINI, N. et al. Histologic effect of mitomycin C on strabismus surgery in the rabbit. Investigative Ophthalmology and Visual Science, Saint Louis, v.41, p.3399-3401, 2000.

$\mathrm{OH}$, S.Y. et al. The effect of mitomycin $\mathrm{C}$ on the healing process in rabbit extraocular muscle surgery. Ophthalmic Surgery Laser, Thorofare, v.30, n.4, p.305-309, 1999.

PARKS, M.M. Atlas of strabismus surgery. Philadelphia: Harper and Row, 1983. 189p.

RIBEIRO, F.A.Q. et al. O comportamento clínico e histológico da pele do rato submetida ao uso tópico e injetável da mitomicina C. Revista Brasileira de Otorrinolaringologia, Rio de Janeiro, v.69, n.2, p.151-158, 2003.

RUBINFELD, R.S. et al. Serious complications of topical mitomycin C after pterygium surgery. Ophthalmology,
Rochester, v.99, p.1647-1654, 1992

SILVA, L.H. Transplante autólogo, homotópico, livre, de músculo ocular extrínseco com e sem uso de antiadesivo: estudo experimental. 1983. 56f. Dissertação (Mestrado em Oftalmologia) - Faculdade de Medicina, Universidade de São Paulo, Ribeirão Preto.

WANG, H.J. et al. A preliminary study on the changes of expression of PDGF-beta, PDGFR-beta, TGF-beta 1, TGFR, bFGF and its relationship with the wound age in wound healing. Fa Yi Xue Za Zhi, Pekin, v.17, n.4, p.198-201, 2001

YAMAMOTO, T. et al. Effects of 5-fluorouracil and mitomycin $C$ on cultured rabbit subconjunctival fibroblasts. Ophthalmology, Rochester, v.97, p.1204-1210, 1990. 